\title{
Energy and macronutrient intake and dietary pattern among Universidade Lusófona students - a pilot study
}

\author{
Consumo de energia e macronutrientes e padrão alimentar nos estudantes da Universidade \\ Lusófona - um estudo piloto
}

\author{
Joana Marcos ${ }^{1}$, Raquel Carriço ${ }^{1}$, Nelson Tavares ${ }^{1,2}$, Carla Sá ${ }^{3,4^{*}}$ \\ ${ }^{1}$ Universidade Lusófona de Humanidade e Tecnologias (ULHT), Lisboa, Portugal; ${ }^{2}$ Centro de Investigação em Biociências e \\ Tecnologias da Saúde da Universidade Lusófona (CBIOS), Lisboa, Portugal; ${ }^{3}$ Centro de Investigação em Desporto, Saúde e \\ Desenvolvimento Humano - ISMAI, Maia, Portugal; ${ }^{4}$ Instituto Politécnico de Bragança, Portugal \\ * Corresponding author: carla.correiadesa@gmail.com
}

\begin{abstract}
Food choices for adopting a healthy lifestyle are influenced by a set of factors. Early adulthood and university entry are crucial for the development of eating habits that will be decisive in quality of life. In Portugal, there are few studies that assess the nutritional status of university students. The main objective of this study, as a pilot study, was to characterize the dietary habits of university students at Universidade Lusófona in Lisbon, Portugal. This cross-sectional descriptive study included university students, aged between 18 and 28 years old. Anthropometric data were collected, and body mass index was calculated. The dietary habits were assessed through a semi-quantitative food frequency questionnaire, administered directly. The average daily intake values were: energy, $2282.9 \pm 954.0 \mathrm{kcal}, 243.2 \mathrm{~g}$ of carbohydrates, $114.2 \mathrm{~g}$ of proteins, and $100.9 \mathrm{~g}$ of lipids. These values include a protein intake of $25.40 \%, 52.11 \%$ carbohydrate and $22.47 \%$ lipids. It was concluded that there is an increase in protein and lipid intake in samples from the university students evaluated.
\end{abstract}

Keywords: University students, food frequency questionnaire, recommended intake

\section{Resumo}

As escolhas alimentares para a adoção de um estilo de vida saudável são influenciadas por um conjunto de fatores. O início da idade adulta e a entrada na Universidade é crucial para o desenvolvimento de hábitos alimentares que serão decisivos na qualidade de vida. Em Portugal, são poucos os estudos que avaliam o estado nutricional de estudantes universitários, como tal, o principal objetivo deste estudo, como um estudo piloto, é avaliar a ingestão alimentar de 52 estudantes universitários da Universidade Lusófona em Lisboa, Portugal. Este estudo descritivo transversal teve como amostra estudantes universitários com idades compreendidas entre os 18 e os 28 anos de idade. Foi administrado de forma direta o questionário semi-quantitativo de frequência alimentar. Os resultados após a análise do questionário reportam que uma ingestão média da amostra corresponde a 2282,9 \pm 954,0 kcal, 243,2 g hidratos de carbono, 114,2 g de proteínas e $100,9 \mathrm{~g}$ de lípidos. Estes valores correspondem a uma percentagem de ingestão de 25,4\% de proteínas, 52,1\% de hidratos de carbono e $22,5 \%$ de lípidos. Conclui-se que existe um aumento da ingestão proteica e lipídica na amostra de estudantes universitários avaliada.

Palavras-chave: Estudantes universitários, questionário de frequência alimentar, ingestão recomendada 


\section{Introduction}

Over the last decades, there has been a significant increase in the study of the importance of adopting healthy lifestyle habits (1-3). However, the increase in eating errors and physical inactivity have been identified as the main factors implicated in the origin of chronic diseases $(2,4)$. In Portugal there has been a progressive loss of most of the characteristics of the traditional dietary pattern and the adoption of a western dietary pattern (5).

Food choices are influenced by a number of factors, including age, gender, lifestyle, beliefs, preferences, and costs. Admission to a university represents, in a way, the transition from youth to early adulthood, characterized by a stressful, tiring, period of more responsibility in regard to housing, financial management, and in particular unhealthy food choices. Several studies reveal that the main determinants of young college students' food choices are the lack of available time, convenience, and cost (6). With the increase of meals taken away from home, the choice of fast food chains and pre-cooked foods is characteristic of this age group (7). Higher education students are a population at risk for nutrient deficiency, especially micronutrients, derived from inadequate eating habits such as low consumption of fruits and vegetables, skipping meals (most commonly breakfast), and high consumption of fast food (8).

Health and good nutritional status are essential to achieve good school performance. Nevertheless, practices of an unhealthy lifestyle inevitably lead to nutritional deficiencies, which are very negative for young people, given the fact that they are in a period of intense and fast growth and unquestionably require the ingestion of all nutrients (9).

Considering these assumptions, this work was mainly focused on the characterization of the eating habits of a sample of university students from Universidade Lusófona in Lisbon, Portugal; it was specifically aimed to assess the caloric and macro and micronutrients intake.

\section{Introdução}

Nas últimas décadas tem-se assistido a um considerável aumento do estudo da importância da adoção de hábitos de vida saudáveis (1-3). No entanto, más práticas alimentares e inatividade física são identificados como os principais fatores implicados na origem de doenças crónicas e ao impacto que estas acarretam para os indivíduos $(2,4)$.

Têm se verificado em Portugal, a perda progressiva da maioria das características do padrão alimentar tradicional e a adoção de um padrão alimentar ocidental (5). As escolhas alimentares são influenciadas por um conjunto de fatores, nomeadamente idade, sexo, estilo de vida, crenças, preferências e custos. A entrada na Universidade representa de certo modo, a transição da juventude para o início da idade adulta, sendo caracterizada por um estilo de vida "stressante", cansativo e de maior responsabilidade em relação à casa, gestão financeira e, em particular, escolhas alimentares pouco saudáveis. Diversos estudos revelam que os principais determinantes das escolhas alimentares dos jovens universitários são a falta de tempo disponível, a conveniência e o custo (6). Com o aumento das refeições realizadas fora de casa, a opção por cadeias de fast food e alimentos pré-confecionados é algo característico desta faixa etária (7). Os estudantes do ensino superior são uma população em risco de deficiências alimentares, principalmente de micronutrientes, derivado de hábitos alimentares desadequados, nomeadamente um baixo consumo de frutos e vegetais, incluindo hortícolas e leguminosas. A frequente omissão de refeições, nomeadamente o pequeno-almoço, a falta de variedade de alimentos ingeridos e o crescente consumo de refeições do tipo fast food são igualmente fatores que promovem deficiências nutricionais (8). A saúde e um bom estado nutricional são essenciais para alcançar um bom desempenho escolar. Contudo, estes tipos de práticas conduzem inevitavelmente à ocorrência de carências nutricionais, algo bastante negativo para os jovens uma vez que se encontram em intenso e rápido crescimento necessitando, inquestionavelmente, da ingestão de todos os nutrientes (9).

Considerando estes pressupostos, este trabalho teve como principal foco a caracterização dos hábitos alimentares de uma amostra de estudantes universitários da Universidade Lusófona, em Lisboa; Portugal, especificamente avaliar a ingestão calórica e de macro e micronutrientes. 


\section{Material and Methods}

This paper is a cross-sectional descriptive study. Data collection took place during May 2019.

\section{Sample}

This study was made from a sample by convenience and consisted of 52 students from multiple courses [Nutrition $(n=34)$, Sports $(n=5)$, Communication $(n=7)$ and Law $(n=6)$ ] of Universidade Lusófona and aged between 18 and 28 years. The total number of students at the Universidade Lusófona was approximately 11,350 (10). Data was obtained after written informed consent, and the questionnaires were conducted anonymously to ensure the confidentiality of the information collected.

\section{Instruments}

Sociodemographic, anthropometric and food intake assessment data were collected. All data was obtained throughthe participants' answers to the questionnaire.

\section{Questionnaires}

For sociodemographic characterization, the following data were collected: age, educational attainment, and personal background. For anthropometric evaluation, data was collected regarding height $(\mathrm{m})$ and weight $(\mathrm{kg})$, and body mass index (BMI) was calculated using the internationally recommended procedures by WHO (11). To assess food intake, a semi-quantitative food frequency questionnaire (FFQ) was applied and administered directly $(12,13)$. In order to avoid biasing the answers, the participants had no prior knowledge of the content of the questionnaires. To obtain food consumption, the frequency reported for each item was multiplied by its standard average portion, in grams, and a seasonal variation factor for food consumed at specific times $(0.25$ was considered the three-month average seasonality).

\section{Statistical analysis}

Data are presented as mean (standard deviation) for cardinal variables, and absolute and relative frequencies $(\%)$ for nominal and ordinal variables. Foods were converted to nutrients using the Food Processor Plus software program (ESHA Research, Salem, OR, USA), with nutrition information from the US Department of Agriculture's food composition tables adapted to typically Portuguese foods. Shapiro-Wilk test was used to test the normality of the distribution of variables. Data was analyzed by SPSS statistical package version 23.0 (IBM Inc., Armonk, New York, USA) and results were considered to be a statistically significant when $p<0.05$.

\section{Material e Métodos}

O presente trabalho constitui um estudo descritivo transversal. A recolha de dados decorreu durante o mês de Maio de 2019.

\section{Amostra}

O estudo foi realizado a partir de uma amostra por conveniência, constituída por 52 estudantes de diversos cursos (Nutrição $(n=34)$, Desporto $(n=5)$, Comunicação $(n=7)$ e Direito $(n=6))$ da Universidade Lusófona de Lisboa com idades compreendidas entre os 18 e 28 anos, considerando o total de alunos da Universidade Lusófona de 11.350 (10) estudantes. Os dados foram obtidos após o consentimento informado escrito, tendo os questionários sido realizados em anonimato para assegurar a confidencialidade da informação recolhida.

\section{Instrumentos}

Foram recolhidos dados sociodemográficos, antropométricos e avaliação da ingestão alimentar. Todos os dados foram obtidos por resposta dos participantes ao questionário.

\section{Questionários}

Para a caracterização sociodemográfica foram recolhidos os seguintes dados: idade, estado civil, habilitações literárias e antecedentes pessoais. Para a avaliação antropométrica foram recolhidos dados referentes à altura (1), peso $(\mathrm{kg})$, e foi feito o cálculo do índice de massa corporal (IMC), usando os procedimentos internacionalmente recomendados pela OMS (11). Para a avaliação da ingestão alimentar recorreu-se à aplicação de um questionário semi-quantitativa de frequência alimentar (QFA), tendo a sua administração sido realizada de forma direta $(12,13)$. De forma a evitar enviesamento das respostas, os participantes não tiveram conhecimento prévio do conteúdo dos questionários. Para a obtenção do consumo alimentar, a frequência referida para cada item foi multiplicada pela respetiva porção média padrão, em grama, e por um fator de variação sazonal para alimentos consumidos em épocas específicas $(0,25$ foi considerada a sazonalidade média de três meses).

\section{Análise Estatística}

Os dados estão apresentados por média (desvio padrão) para variáveis cardinais, e frequências absolutas e relativas (\%) para as variáveis nominais e ordinais. A conversão dos alimentos em nutrientes foi efetuada utilizando como base o programa informático Food Processor Plus (ESHA Research, Salem, OR, USA), com 


\section{Results}

\section{Sample Characterization}

The sample consisted of 52 university students from the Universidade Lusófona , 59.6\% women and 40.4\% men. The majority of students $(65.4 \%)$ were in Nutrition course, and the mean age of the sample was $21.2 \pm$ 1.8 years (range: 18 to 28 ). The average body mass index was $20.5 \pm 5.6 \mathrm{~kg} / \mathrm{m}^{2}$. All participants did not have any associated pathology known to date.

\section{Dietary Intake Assessment}

The food intake of the participating students after conversion to nutrients is shown in Table 1, i.e., the values of the average daily macronutrient intake and energy obtained, after analyzing the food frequency questionnaire data.

Table 1 shows that the average intake of the sample corresponds to $2282.9 \pm 954.0 \mathrm{kcal}$. These results are not in accordance with those presented in Dietary Reference Values of European Food Safety Authority $(14,15)$. The possibility of inaccuracy of the referenced foods, as well as the concealment of the consumption of some foods, may explain the lower energy consumption (below the recommendations). informação nutricional proveniente de tabelas de composição de alimentos do Departamento de Agricultura dos Estados Unidos da América, adaptada a alimentos tipicamente Portugueses. O teste de Shapiro-wilk foi utilizado para testar a normalidade da distribuição das variáveis. Os dados foram analisados pelo SPSS statistical package version 23.0 (IBM Inc., Armonk, New York), sendo considerado um resultado com significado estatístico, quando $\mathrm{p}<0,05$.

\section{Resultados}

\section{Caracterização da Amostra}

A amostra foi constituída por 52 estudantes universitários da Universidade Lusófona, em Lisboa, sendo que $59,6 \%$ sexo feminino e $40,4 \%$ sexo masculino. A maioria dos estudantes $(65,4 \%)$ são do curso de Nutrição, e a média de idades da amostra foi de 21,2 $\pm 1,8$ anos (variação entre 18 e os 28 anos). A média de índice de massa corporal foi de $20,5 \pm 5,6 \mathrm{~kg} / \mathrm{m}^{2}$. Todos os participantes não têm qualquer patologia associada, conhecida até à data.

\section{Ingestão Alimentar}

A ingestão de alimentos após a conversão em nutrientes está representada na Tabela 1, ou seja, os valores da ingestão média diária de macronutrientes e energia obtidos após a análise dos dados do questionário de frequência alimentar.

A tabela 1 mostra que a ingestão média da amostra corresponde a $2282,9 \pm 954,0 \mathrm{kcal}$, estes resultados não

Table 1 - Caloric intake (kcal), protein (grams), carbohydrates and lipids in university students $(\mathrm{n}=52)$ of the Lusófona University of Lisbon

Tabela 1 -Ingestão calórica (kcal), proteínas (gramas), hidratos de carbono e lípidos em estudantes universitários $(\mathrm{n}=52)$ da Universidade Lusófona de Lisboa

\begin{tabular}{|c|c|c|c|c|c|c|}
\hline & $\mathbf{n}$ & $\begin{array}{c}\text { Minimum/ } \\
\text { Mínimo }\end{array}$ & $\begin{array}{c}\text { Maximum/ } \\
\text { Máximo }\end{array}$ & $\begin{array}{c}\text { Average/ } \\
\text { Média }\end{array}$ & $\begin{array}{c}\text { Standard } \\
\text { Deviation/ Desvio } \\
\text { Padrão }\end{array}$ & $\begin{array}{c}\text { Percentage/ } \\
\text { Percentagem }\end{array}$ \\
\hline $\begin{array}{c}\text { Calories (kcal)/ } \\
\text { Calorias (Kcal) }\end{array}$ & 52 & 1142.1 & 5271.9 & 2282.9 & 954.0 & - \\
\hline $\begin{array}{c}\text { Proteins/ } \\
\text { Proteinas }\end{array}$ & 52 & 28.5 & 260.3 & 114,2 & 52.7 & $25.4 \%$ \\
\hline $\begin{array}{c}\text { Carbohydrates/ } \\
\text { Hidratos de } \\
\text { Carbono }\end{array}$ & 52 & 68.8 & 519.7 & 234.2 & 101.4 & $52.1 \%$ \\
\hline \begin{tabular}{c} 
Lipids/ Lipidos \\
\hline
\end{tabular} & 52 & 37.9 & 240.2 & 100.9 & 46.8 & $22.5 \%$ \\
\hline
\end{tabular}


Table 2 Comparison of the average daily intake of nutrientes by sex in university students $(n=52)$ of the Universidade Lusófona of Lisbon

Tabela 2 -Comparação do consumo médio diário de nutrientes por sexo em estudantes universitários $(\mathrm{n}=52)$ da Universidade Lusófona de Lisboa

\begin{tabular}{|c|c|c|c|}
\hline & $\begin{array}{c}\text { Male/Masculino } \\
(\mathbf{n = 2 1})\end{array}$ & $\begin{array}{c}\text { Female/Feminino } \\
(\mathbf{n}=\mathbf{3 1})\end{array}$ & $\boldsymbol{p}$ value $^{\mathbf{1}}$ \\
\hline Calories (kcal)/ Calorias (Kcal) & $2605.4 \pm 266.2$ & $2064.5 \pm 118.2$ & 0.074 \\
\hline Proteins/ Proteínas (g) & $127.1 \pm 13.9$ & $105.4 \pm 7.6$ & 0.183 \\
\hline Carbohydrates/ Hidratos de Carbono (g) & $279.8 \pm 25.8$ & $203.3 \pm 75.5$ & $\mathbf{0 . 0 1 3}$ \\
\hline Lipids/ Lípidos (g) & $110.6 \pm 12.6$ & $94.4 \pm 37.3$ & 0.265 \\
\hline
\end{tabular}

${ }^{1} \mathrm{p}$-value for the comparison between male and female considered a result with statistical significance when $\mathrm{p}<0.05$.

Regarding the macronutrients consumed, an average intake of $243.2 \mathrm{~g}$ carbohydrates, $114.2 \mathrm{~g}$ of protein, and $100.9 \mathrm{~g}$ of lipids was determined. These values correspond to a protein intake of $25.4 \%, 52.1 \%$ carbohydrate, and $22.5 \%$ lipids. When comparing differences between sex, we did not obtain statistically significant differences (Table 2), except in carbohydrates $(\mathrm{p}<$ 0.05). Male participants had a higher carbohydrates intake then female participants, and according to the Directorate General of Health (DGS) recommendations, the percentage of carbohydrates recommended (55 to $75 \%$ ) is slightly higher than that obtained. However, because this disparity is not high, it is not considered of great relevance (16).

The current nutritional recommendations for total energy value, as a percentage, indicate a protein intake of between 10 and $15 \%$, carbohydrates between 55 to $75 \%$, and lipids between 15 to $30 \%$. The intake values of the study sample are within the recommendations, however, the protein intake of the study sample is $10 \%$ higher than recommended (Figure 1). The increase in protein intake by the sample under study may be due to the fact that college students and the Portuguese population (in general) consume more eggs, meat, and fish group than other food groups . It is important to highlight that this protein intake, mainly due to meat, suggests that there may be excess saturated fat, registered in this study at $28.5 \pm 14.8 \mathrm{~g}$.

Moreover, the lipids are within the recommended values, although slightly higher than the recommended average intake. The range is due to the high consumption of products from the "sweets and pastries" group or the use of "oils and fats" for seasoning (14). It should be noted that although lipids are essential in a balanced diet, in this case this discrepancy arises from meals estão de acordo com os valores de referência da EFSA $(14,15)$. A possibilidade de imprecisão dos alimentos referenciados, bem como a ocultação do consumo de alguns alimentos, poderá explicar os consumos energéticos inferiores às recomendações. Relativamente aos macronutrientes consumidos verifica-se que uma ingestão média de 243,2 g hidratos de carbono, 114,2 $\mathrm{g}$ de proteínas e 100,9 g de lípidos. Estes valores correspondem a uma percentagem de ingestão de $25,4 \%$ de proteínas, $52,1 \%$ de hidratos de carbono e $22,5 \%$ de lípidos. Ao comparar as diferenças entre sexos, não obtivemos diferenças estatisticamente significativas (Tabela 2), exceto nos hidratos de carbono $(\mathrm{p}<0,05)$ que os homens ingerem em média uma quantidade superior em relação às mulheres, e de acordo com as recomendações da DGS, a percentagem de hidratos de carbono recomendada (55 a 75\%), encontra-se ligeiramente superior à obtida, contudo devido a esta disparidade não ser elevada não se considera de grande relevância.

As recomendações nutricionais atuais para o valor energético total, em percentagem, declaram um consumo de proteínas entre 10 e $15 \%$, hidratos de carbono de 55 a $75 \%$, lípidos de 15 a 30\% (16). O que comparado com os valores de ingestão da amostra em estudo, está dentro das recomendações, no entanto o valor da ingestão proteína da amostra é $10 \%$ superior ao recomendado (Figura 1). O aumento da ingestão de proteínas pela amostra em estudo, poder-se-á dever ao facto de os estudantes universitários consumirem mais alimentos do grupo dos "ovos, carnes e peixes" do QFA, do que outros grupos de alimentos. É importante destacar que este consumo proteico por advir principalmente das carnes, sugere que possa haver um excesso de gordura saturada, neste estudo foi de $28,5 \pm 14,8 \mathrm{~g}$.

No caso dos lípidos está dentro dos valores recomen- 
Figure 1 - Comparison between the daily intake of macronutrients (protein, percentage carbohydrates) between the sample of university students $(n=52)$ and the values recommended by the Directorate General of Health (DGS)

Figura 1 - Comparação entre a ingestão diária de macronutrientes (proteínas, hidratos de carbono em percentagem) entre a amostra de estudantes universitários $(n=52)$ e os valores recomendados pela direção geral de saúde (DGS)

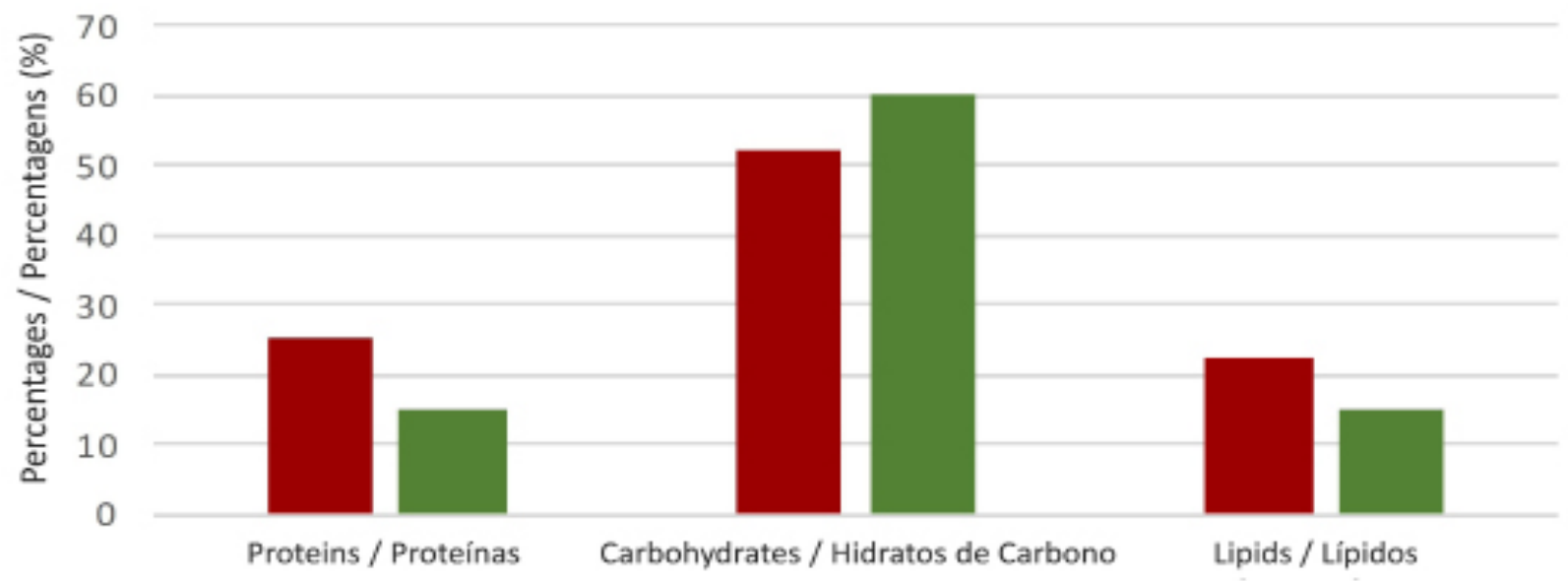

Macronutrients / Macronutrientes

Sample values / Valores obtidos pela população em estudo

Recommendations / Valores recomendados pela DGS

based on processed food and high energy density foods, high in fat and sugars often eaten between meals.

There is an unbalanced dietary pattern associated with a sedentary lifestyle related to a change in macronutrient density in the diet, i.e., a higher amount of protein and lipids than carbohydrates. The diet of a typical young college student is predominant in foods rich in total fat, saturated fat, and cholesterol, and poor in fruits and vegetables (17). The concept of a traditional meal has been changing in both composition and cooking. This change is due to inconsistent school schedules, increased study demands, a lack of time management for household chores, separation from family, and a preference to consume meals away from home. Thus, according to Bernardo et al. (18), the lack of variety in college students' intake could be due, to an increase in the number of meals eaten in restaurants or pre-prepared because of the vast availability of fast and easily accessible food (fast food and snacks), as well as convenience, cost and the frequent omission of meals, namely breakfast and midday snacks.

This work has some limitations, the small number of participants limits the scope of this work, however, as a pilot study it is suitable for future development in this theme. dados, apesar de ser um pouco superior à média de ingestão recomendada. O intervalo deve-se ao grande consumo de produtos do grupo "Doces e pastéis" ou à utilização de "Óleos e gorduras" para temperar (14). É de referir que apesar de os lípidos serem essenciais numa alimentação equilibrada, neste caso esta discrepância surge devido a refeições baseadas em comida processada, em alimentos com elevada densidade energética, ricos em gorduras e açúcares muitas vezes consumidos fora das refeições.

Nota-se um padrão alimentar desequilibrado associado a um estilo de vida sedentário relacionado com uma mudança da densidade de macronutrientes na dieta, ou seja, uma maior quantidade de proteínas e lípidos que hidratos de carbono. A alimentação de um típico jovem universitário predomina em alimentos ricos em gordura total, saturada e colesterol sendo pobre em frutas e hortícolas (17). O conceito de refeição tradicional tem vindo a alterar-se, tanto na composição como na confeção. Esta mudança deve-se a horários escolares desencontrados, maiores exigências no estudo, a uma falta de gestão de tempo de tarefas domésticas, afastamento da família e, não menos importante, o consumo preferencial de refeições realizadas fora de casa. Assim, a falta de variedade na ingestão dos estudantes univer- 


\section{Conclusion}

Thus, our study concludes that there is an increase in protein intake in the sample of college students evaluated. This increase may trigger repercussions on future health, not only because of the protein intake, but also the the saturated fat intake, which may be accentuated by a decrease in healthy eating habits as they are in college education. Considering the limitations of this work, this preliminary data gives us an idea that the introduction of food education lectures will be necessary to inform the population how to have a healthy diet and to give some advice about cooking.

\section{Conflict of interest}

No conflicts of interest sitários poderá ser explicada, de acordo com Bernardo et al. (18), por um aumento na quantidade de refeições consumidas em restaurantes ou pré-preparadas devido à disponibilidade de comida de fácil e rápido acesso (fast food e snacks), bem como a conveniência, o custo e a frequente omissão de refeições, nomeadamente o pequeno almoço e o lanche.

Este trabalho tem algumas limitações, o pequeno número de participantes limita o escopo deste trabalho, no entanto, como um estudo piloto, ele é adequado para o desenvolvimento futuro deste tema.

\section{Conclusão}

Deste modo, conclui-se que existe um aumento da ingestão proteica na amostra de estudantes universitários avaliada, este aumento poderá desencadear repercussões no estado de saúde futuro, não apenas pela quantidade de ingestão de proteínas, mas pela quantidade de ingestão de gordura saturada, que poderá ser acentuado por um decréscimo nos hábitos alimentares à medida que se encontram no ensino universitário. Considerando as limitações deste trabalho, estes dados preliminares indicam que é necessário a introdução de palestras de educação alimentar, com o intuito de informar a população sobre a adoção de um estilo de vida saudável e alguns conselhos sobre confeções saudáveis.

\section{Conflitos de interesse}

Não existem conflitos de interesse 


\section{References / Referências}

1. Eze NM, Maduabum FO, Onyeke NG, Anyaegunam NJ, Ayogu CA, Ezeanwu BA, et al. Awareness of food nutritive value and eating practices among Nigerian bank workers Implications for nutritional counseling and education. Medicine. 2017;96(10).

2. Yahia N, Wang D, Rapley M, Dey R. Assessment of weight status, dietary habits and beliefs, physical activity, and nutritional knowledge among university students. Perspect Public Health. 2016;136(4):231-44.

3. Almutairi KM, Alonazi WB, Vinluan JM, Almigbal TH, Batais MA, Alodhayani AA, et al. Health promoting lifestyle of university students in Saudi Arabia: a cross-sectional assessment. BMC Public Health. 2018;18(1):1093.

4. Ssewanyana D, Abubakar A, van Baar A, Mwangala PN, Newton CR. Perspectives on Underlying Factors for Unhealthy Diet and Sedentary Lifestyle of Adolescents at a Kenyan Coastal Setting. Front Public Health. 2018;6.

5. Cruz JA. Dietary habits and nutritional status in adolescents over Europe--Southern Europe. Eur J Clin Nutr. 2000;54 Suppl 1:S29-35.

6. Davy SR, Benes BA, Driskell JA. Sex differences in dieting trends, eating habits, and nutrition beliefs of a group of Midwestern college students. J Am Diet Assoc. 2006;106(10):1673-

7. Tam R, Yassa B, Parker H, O'Connor H, Allman-Farinelli M. University students' on-campus food purchasing behaviors, preferences, and opinions on food availability. Nutrition. 2017;37:7-13.

8. Unusan N. University students' food preference and practice now and during childhood. Food Qual Prefer. 2006;17(5):362-8.

9. Kim SY, Sim S, Park B, Kong IG, Kim JH, Choi HG. Dietary Habits Are Associated With School Performance in Adolescents. Medicine (Baltimore). 2016;95(12):e3096.

10. Lusófona U. RELATÓRIO ANUAL 2017-18 https://www.ulusofona.pt/pt/media-ref/relatorio-anual-2017-18/download/relatorio-anual-2017-18. pdf2019

11. Nuttall FQ. Body Mass Index: Obesity, BMI, and Health: A Critical Review. Nutr Today. 2015;50(3):117-28.

12. Lopes C, Aro A, Azevedo A, Ramos E, Barros H. Intake and adipose tissue composition of fatty acids and risk of myocardial infarction in a male Portuguese community sample. J Am Diet Assoc. 2007;107(2):276-86.

13. Lopes C. Reprodutibilidade e Validação de um questionário semi-quantitativo de frequência alimentar. In: Alimentação e enfarte agudo do miocárdio: um estudo caso-controlo de base populacional: Universidade do Porto; 2000.

14. Lopes C, Torres D, Oliveira A, Severo M, Guiomar S, Alarcao V, et al. National Food, Nutrition, and Physical Activity Survey of the Portuguese General Population (2015-2016): Protocol for Design and Development. JMIR Res Protoc. 2018;7(2):e42.

15. (EFSA) EFSA. Dietary Reference Values for nutrients www.efsa.europa.eu/publications2019 [

16. Candeias V, Nunes, E., Morais, C., Cabral, M., \& Ribeiro da Silva, P. . Princípios para uma Alimentação Saudável.: Direção Geral de Saúde; 2005 [

17. Nicklas TA, Baranowski, T., Baranowski, J. C., Cullen, K., Rittenberry, L., \& Olvera, N. . Family and child-care provider influences on preschool children's fruit, juice and vegetable consuption. Nutrition Review. 2001;59:224-30.

18. Bernardo GL, Jomori MM, Fernandes AC, Colussi CF, Condrasky MD, Proenca R. Nutrition and Culinary in the Kitchen Program: a randomized controlled intervention to promote cooking skills and healthy eating in university students - study protocol. Nutr J. 2017;16(1):83. 